\title{
47. SYNTHESIS OF THE LEG 27 BIOSTRATIGRAPHY AND PALEONTOLOGY
}

\author{
H. M. Bolli, Geology Department, Swiss Federal Institute of Technology, \\ Zurich, Switzerland
}

\section{INTRODUCTION}

Of the five sites drilled, four $(259,260,261$, and 263$)$ are situated in deep basins with a much-reduced and stratigraphically incomplete Cenozoic section, an almost nonexistent Upper Cretaceous section, and about 120 meters to over 600 meters of Lower Cretaceous sediments overlying basalt basement. At Site 261 the sediments immediately above basement are dated on nannoplankton as Upper Jurassic. Basalt was reached at three of the four abyssal plain sites, but at Site 263 drilling was terminated for technical reasons immediately above basement. Site 262 , drilled in relatively shallow water in the western Timor Trough, penetrated a thick plankton-rich Holocene to Pleistocene section and bottomed in shallow-water calcarenite of Pliocene age.

Figures 1-5 show for each site the distribution and frequency of the investigated faunal/floral groups and the ages based on them.

\section{CENOZOIC}

Faunal interpretations and age assignments of the much-reduced and stratigraphically incomplete Cenozoic, ranging from about 70 meters to a maximum of about 170 meters at Sites 259, 260, 261, and 263, posed no particular problems. Detailed faunal studies were not carried out in the sediments of these sites, which largely corisist of turbidites. Except for the Pleistocene, the faunas/floras were found to be irregularly distributed, mostly fairly scarce, poor in preservation and, as a result of reworking and redeposition, often heterogeneous in their composition. At these sites the Quaternary is restricted to the top one or two cores. At Site 263 the Quaternary is about 100 meters thick but only three cores were taken in this interval. Notable is an unusual lower Paleocene planktonic foraminiferal fauna, consisting of small globigerinids of Globigerina eugubina Zone aspect, and of little known, comparatively large quadriserial Heterohelicidae, recovered from Core 4 at Site 263, an interval in which frequent reworked Cretaceous elements also occur.

The only Paleogene sequence of significant thickness occurs at Site 259, where all the lower Eocene and the uppermost Paleocene nannoplankton zones were recorded in Cores 4-7, with the ages also being confirmed by foraminifera.

The only Pliocene-Quaternary sequence studied paleontologically in more detail is that of Site 262 situated in the Timor Trough. Of the 442 meters drilled and continuously cored, the upper 337.5 meters are Pleistocene-Holocene based on planktonic foraminifera, the lower 100 meters, Pliocene. The sequence, except for the bottom part in which rapid shallowing takes place, is rich in planktonic organisms. Euxinic bottom conditions for the Holocene and most of the Pleistocene are indicated by the very rich plankton and the virtual absence of benthos, the sediment character, and the high content of methane in some parts of the section. These features compare with those existing in the Cariaco Trough, Site 147 of Leg 15, off the north coast of Venezuela, where euxinic bottom conditions also prevail.

The plankton-rich Site 262 Holocene-Pliocene section with the high average sedimentation rate of approximately $15-19 \mathrm{~cm} / 1000 \mathrm{yr}$, was ideal for investigations of evolutionary trends in planktonic foraminifera. Trends were investigated in particular for the Globorotalia crassaformis-tosaensis-truncatulinoides groups of planktonic foraminifera, taxa widely used as index forms in Pliocene-Quaternary biostratigraphy. The paper on this subject by Rögl (this volume) is a documentation of Pliocene/Pleistocene planktonic foraminiferal evolutionary trends and their application to biostratigraphy, likely to be of use over wide areas within the subtropical/tropical belt. Notable also is the fact that the subdivision of the Quaternary as proposed for the Caribbean by Bolli and Premoli Silva (1973) could be applied to Site 263, and thus become of more than only local significance.

Quaternary diatoms at Site 262 were also investigated in some detail. Like the Radiolaria, they make their first appearance within the lower part of the Pleistocene (about $250 \mathrm{~m}$ below sea floor), indicating a major ecological event at this level, shown also by changes in the calcareous plankton association. Based on frequencies, and changes in the association of taxa, Jouse and Kazarina (this volume) distinguish five zones. Those most extended and rich in diatoms are an upper Pleistocene zone (Zone I, Cores 1-11), with an association comparable to the Recent Indian Ocean warm-water diatom flora, and a middle Pleistocene zone (Zone II, Cores 13-25), with an older flora indicating somewhat colder water conditions.

No generally accepted agreement exists on where to place the Pliocene/Pleistocene boundary based on planktonic microorganisms. A number of authors use Globorotalia truncatulinoides truncatulinoides as an index. Others base it on the first evolutionary appearance of this taxon at approximately $1.8 \mathrm{~m} . \mathrm{y}$. Others prefer to have it somewhat higher, at a level where the percentage of $G$. truncatulinoides tosaensis and $G$. truncatulinoides truncatulinoides reach $50 \%$ each.

Based on calcareous nannoplankton, the Pliocene/Pleistocene limit is determined by some authors to be where Discoaster abundance including $D$. hrouweri decreases markedly at about 2.5 m.y. Ac- 


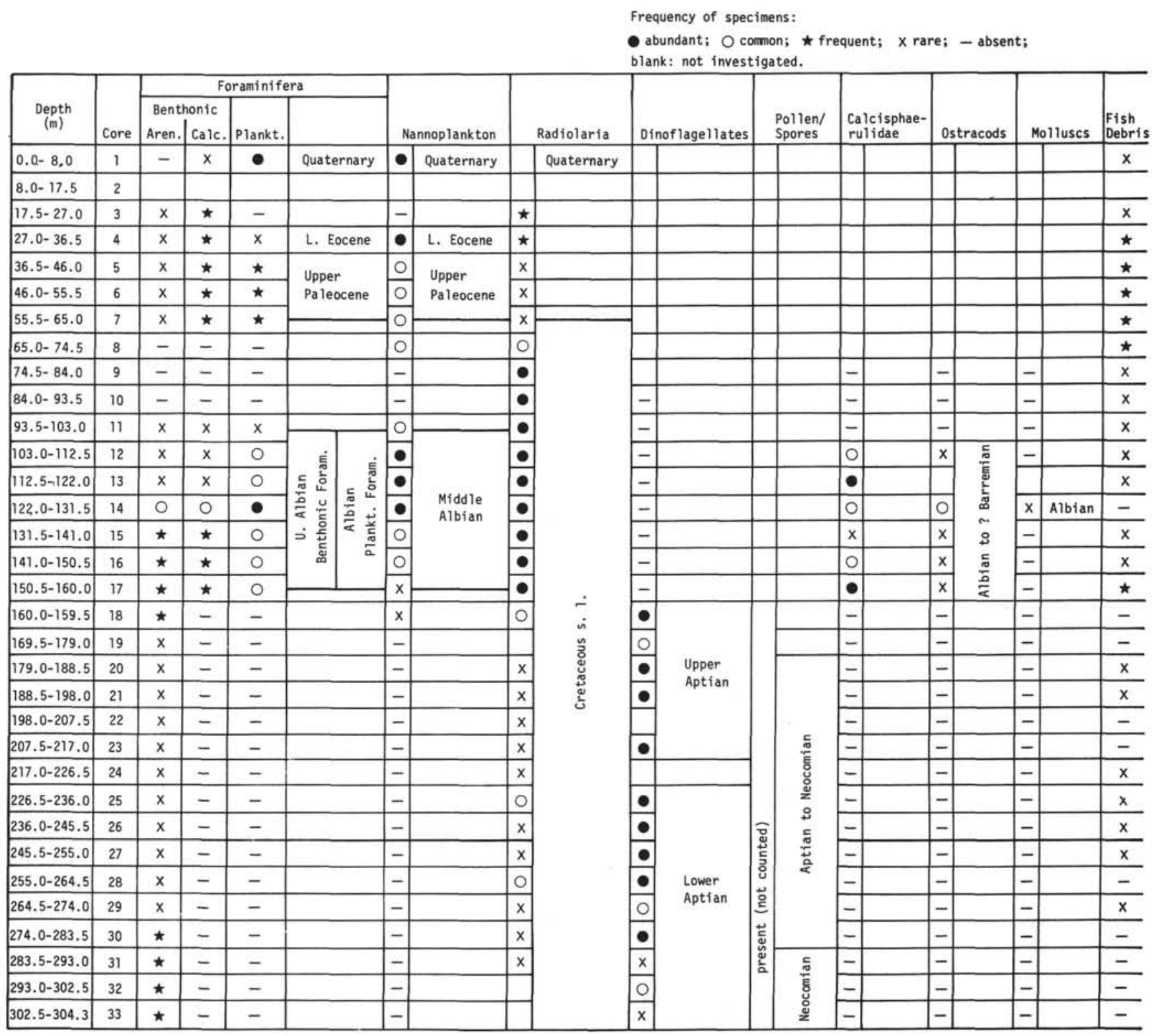

Figure 1. Distribution, age, and frequency of investigated fossils, Site 259.

cording to those authors Discoaster does not become extinct at this level, but continues in a much reduced and irregular way because of cooling. Shortly after the first appearance of $G$. truncatulinoides truncatulinoides there takes place again a slight and short lived increase, after which the genus becomes finally extinct.

At Site 262, G. truncatulinoides truncatulinoides first appear in Core 36, CC at 337.5 meters, the sharp decrease in Discoaster peak with D. brouweri falls within Core 44 at 407 meters, with a weak reappearance of Discoaster in Cores 33 and 32. The position of the Pliocene/Pleistocene boundary at Site 262 thus varies considerably, depending on which of the above criteria is applied. Based on nannoplankton, it lies within Core 44 and on $G$. truncatulinoides truncatulinoides at the base of Core 36, a difference of some 70 meters.

\section{MESOZOIC}

With few exceptions, the faunas and floras of the Mesozoic are poor, monotonous, and often of inferior preservation. Over long intervals it was therefore difficult to arrive, on paleontological grounds, at reasonably accurate and reliable age assignments. In view of the importance of obtaining accurate ages of the Mesozoic sections, in particular their basalt parts overlying basaltic basement, special efforts were undertaken to arrive at biostratigraphic results. All microfaunas and floras thought to offer information on age and ecology were therefore investigated. They include planktonic and benthonic foraminifera, calcareous nannoplankton, radiolaria, dinoflagellates, pollen/spores, ostracods, and molluscs. Fish debris was 


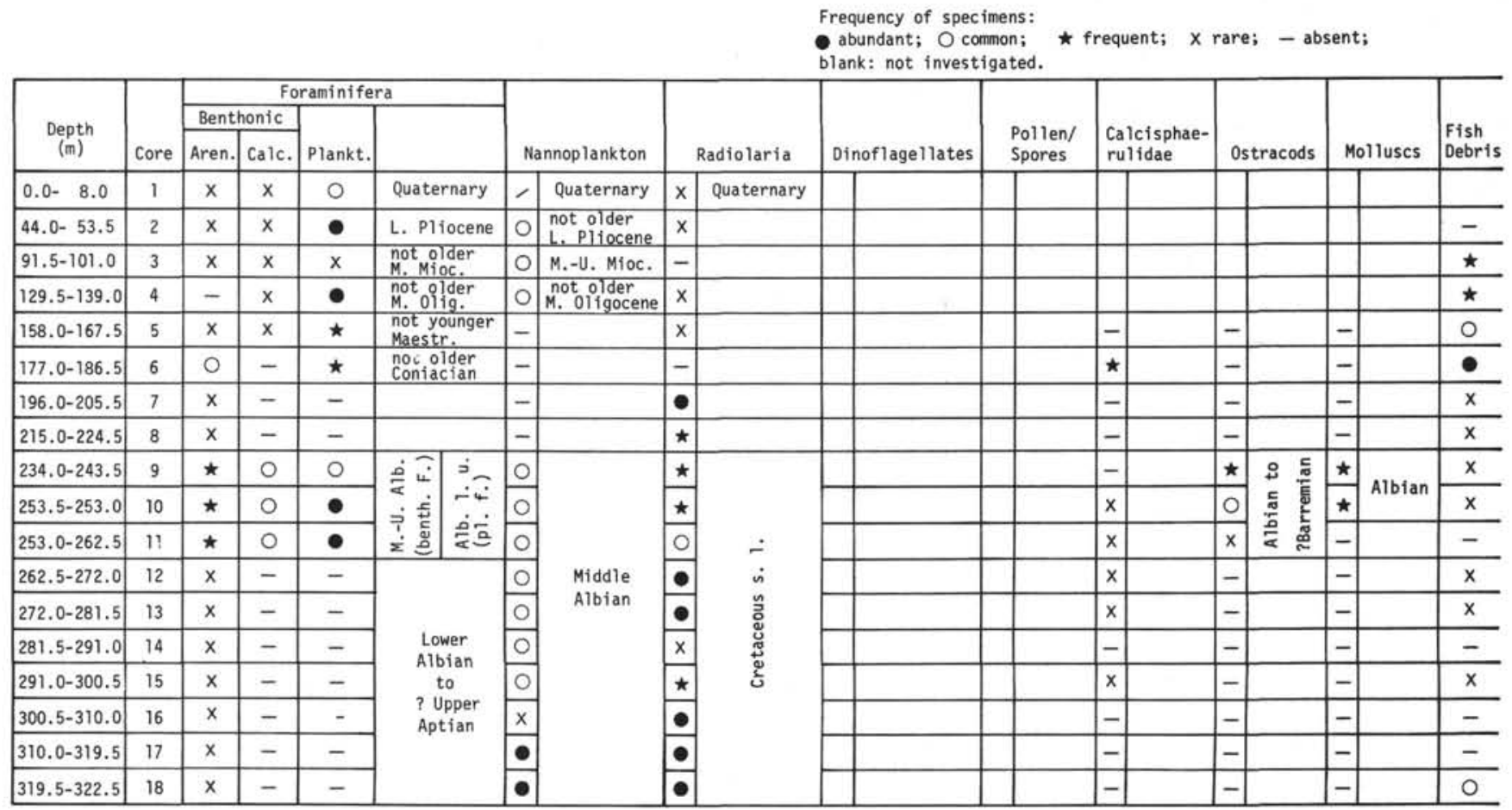

Figure 2. Distribution, age, and frequency of investigated fossils, Site 260.

also noted and indicated for future reference, but was not investigated here. Arenaceous foraminifera are present in almost all examined Mesozoic samples but are sparse in number and composed mostly of primitive genera.

Except at Site 263, Radiolaria are frequent in most Lower Cretaceous cores. Because of their poor preservation and the limited information available on their distribution in the Lower Cretaceous, Radiolaria did not offer much stratigraphic information for the Initial Report. The Leg 27 Radiolaria are described and figured by Renz (this volume).

Other microfossils, like calcareous foraminifera, nannoplankton, palynomorphs, ostracods, and in particular molluscs, were found restricted often to only short intervals. The sporadic appearance of many of the more valuable biostratigraphic fossils such as planktonic foraminifera, nannoplankton, and diagnostic calcareous benthonic foraminifera made accurate age assignments of the sediments often difficult or tentative, particularly for those sediments immediately overlying basement.

Upper Cretaceous sediments are completely absent at Sites 259 and 263, and only occur in much reduced thickness at Site 260, Core 6; and Site 261, Cores 5-8. These sediments consist of zeolite clays thought to have been laid down below the lysocline. They contain an arenaceous foraminiferal fauna of unusual appearance, the tests of which are very small, the walls thin, fine grained or almost homogeneous, and the surface smooth. Faunas like this have previously been recovered only in some deep-water clays of Leg 20 in the Pacific, where they occur with Upper Cretaceous Radiolaria.

Based on its distribution at Site 261, this arenaceous fauna which is diverse in genera and species, many of them new, can be subdivided there into an upper and a lower assemblage. The upper assemblage alone is present in Core 6 of Site 260 and also in Leg 20 of the Pacific.

The Site 260 arenaceous fauna is accompanied by planktonic foraminifera of ?Albian, Cenomanian, and not older than Coniacian age. Because of its heterogeneous composition, it is considered reworked or redeposited, carried down from higher levels, and buried again below the lysocline on the clays, together with the autochthonous arenaceous forms.

Once their ages and ranges are better known, these deep-water assemblages of arenaceous foraminifera may eventually become useful for dating and correlating clays deposited below the lysocline and void of other index fossils.

Planktonic foraminifera are fairly frequent and of use for dating Lower Cretaceous sediments only in two short intervals, Cores 11-17 at Site 259 and Cores 9-11 at Site 260. They are described and figured by Krasheninnikov (this volume, Chapter 33), who dates those at Site 259 as Albian and those at Site 260 as ?upper Albian. Benthonic calcareous and arenaceous foraminifera are also frequent in these intervals. Except for Cores $30-32$ at Site 259, where arenaceous foraminifera are frequent, and Cores $30-33$ at Site 261 and Cores 17-29 at Site 263, where calcareous and arenaceous forms are frequent to common, the other Lower Cretaceous sediments drilled only contain poor, mainly primitive arenaceous foraminifera.

The benthonic foraminiferal assemblages, in particular the calcareous assemblages, were found useful for dating the sediments and interpreting the paleoenvironment. The Albian-Aptian benthonic foraminifera at Sites 259, 260, and 263 described and 


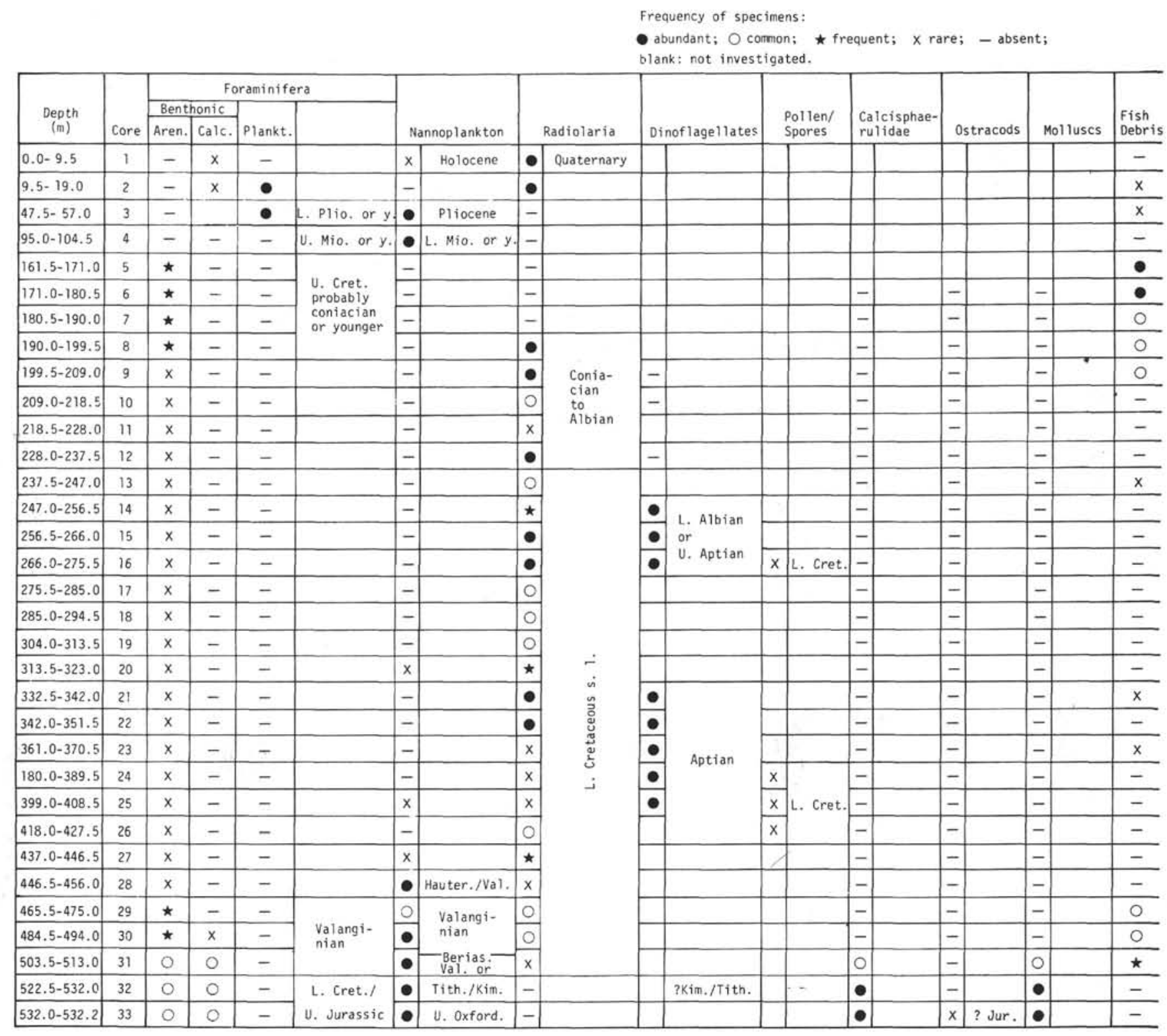

Figure 3. Distribution, age, and frequency of investigated fossils, Site 261.

figured by Scheibnerova (this volume) allow for close comparison with known Australian faunas, in particular from the Great Artesian Basin and the Canning Basin. Conclusions on age and ecology were drawn largely from such correlations.

The benthonic calcareous multichambered arenaceous foraminifera of the Lower Cretaceous/Upper Jurassic at Site 261, Cores 28-33, are described, and figured by Kutznetsova (this volume). Her conclusions are that no real index forms are present which would allow for reliable stratigraphic dating, though some species from the deeper cores are indicative for Upper Jurassic, and some from the higher cores are known from the Lower Cretaceous Valanginian.

Bartenstein (this volume) investigated the primitive arenaceous foraminifera only, that is the one- and twochambered forms, at Site 261, Cores 29-33 and also at Site 259, Core 32. These taxa allow for no age determination, but are useful as ecological indicators.

Calcareous nannoplankton is also abundant in Cores 11-17 at Site 259 and in Cores 9-11 at Site 260, where it also continues to be frequent until the bottom of Core 18. Nannoplankton is virtually absent at Site 261, Cores 5-27, dated by other fossil evidence as Albian-Aptian, but becomes abundant in the basal part of this site, in Cores 28-33, where it indicates a sequence ranging from upper Oxfordian to Hauterivian/Valanginian.

The distribution pattern of nannoplankton is variable in the Lower Cretaceous at Site 263. It is common in Cores 5-7 and 22-29, scarce in the interval in between Cores 8-21. The interval Cores 5-27 is dated upper Albian, based on Eiffellithus turriseiffeli, a generally accepted index form common to rare in Cores 22-27. The calcareous nannoplankton is described and figured and the ages and ranges discussed by Proto Decima (this volume). 
Frequency of specimens:

- abundant; Ocommon; $\star$ frequent; $x$ rare; - absent;

blank: not investigated.

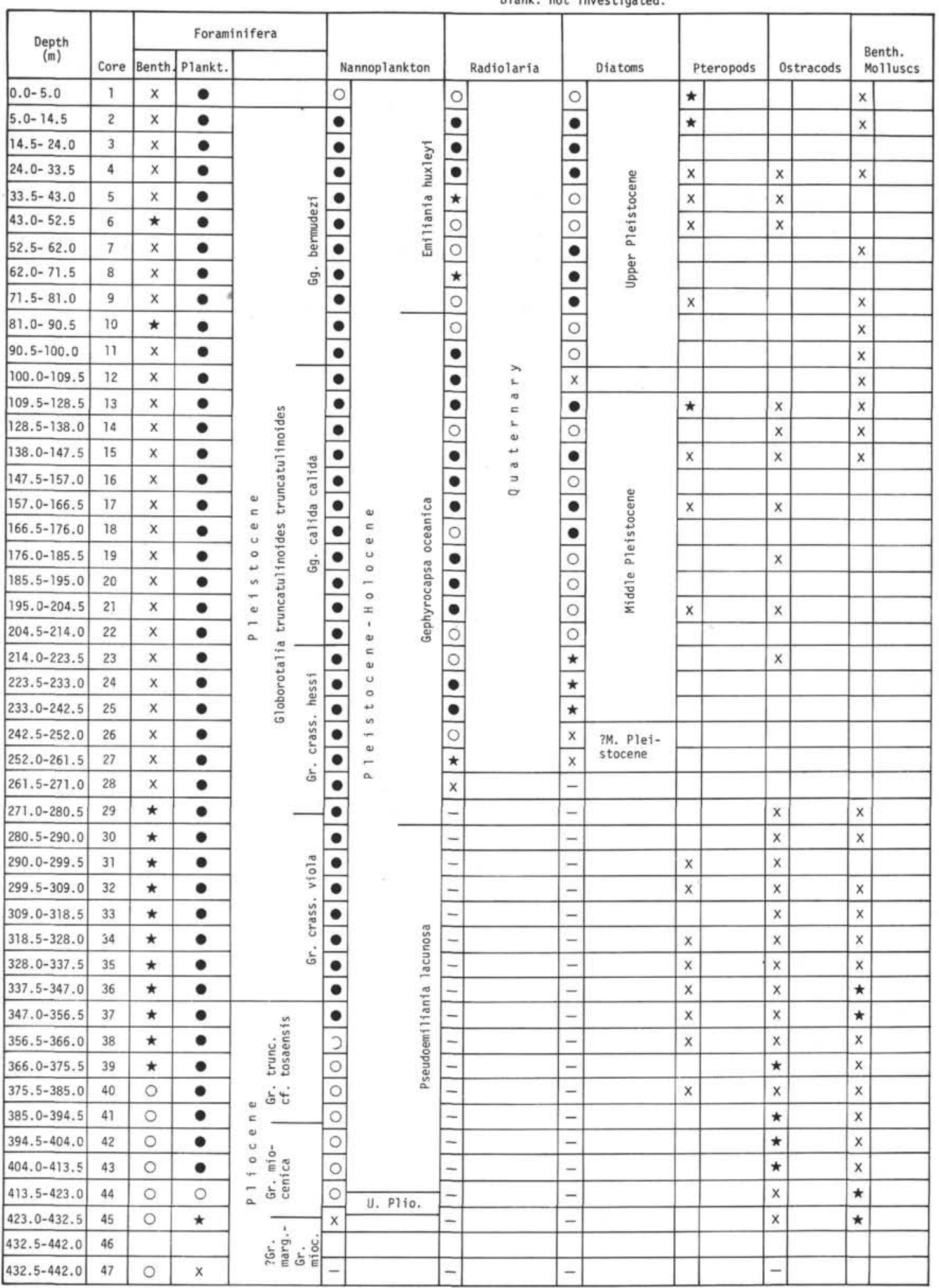

Figure 4. Distribution, age, and frequency of investigated fossils, Site 262. 


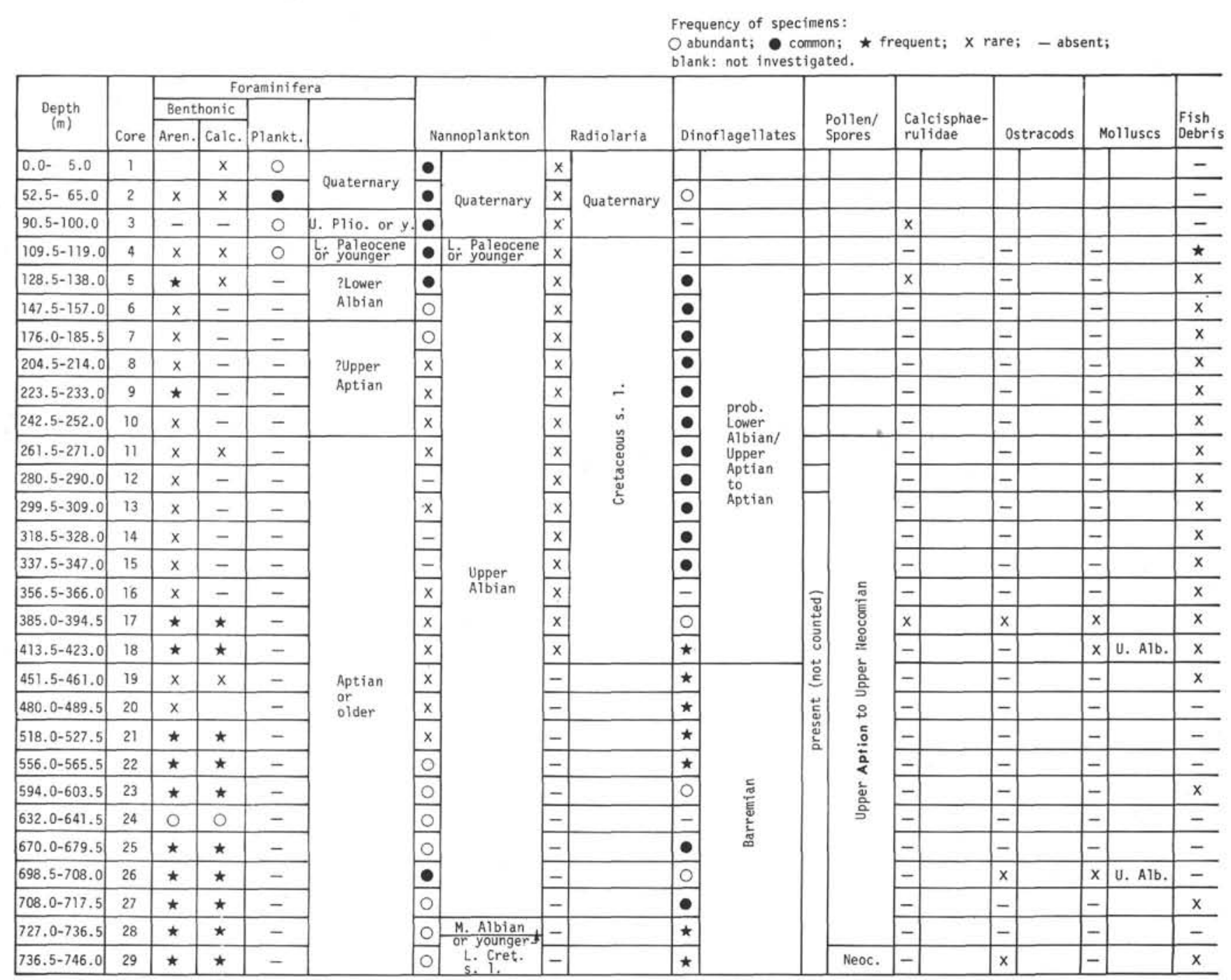

Figure 5. Distribution, age, and frequency of investigated fossils, Site 263.

Mesozoic sediments at Sites 259, 261, and 263 were studied for dinoflagellates, pollen, and spores. Most of the investigated samples yielded varied and wellpreserved associations of predominantly marine palynomorphs. Their occurrence and distribution of palynomorphs at these sites is discussed by Wiseman and Williams (this volume), who compare their ages and ranges with a world-wide range chart compiled by them. Palynomorphs at Sites 259 and 261 are largely complementary in their occurrence relative to calcareous foraminifera and nannoplankton. This aids in a more complete biostratigraphic interpretation of the intervals concerned and should also be of paleoecological significance.

Lower Cretaceous ostracods are described and figured by Oertli (this volume). They are largely confined to Cores 12-17 at Site 259 and to Cores 9-11 at Site 260, where they are associated with rich foraminiferal and nannoplankton faunas. They are rare and their occurrence is restricted to a very few samples at Sites 261 and 263. Most of the specimens were identifiable on the generic level, but could not be assigned to existing species. Ages are very tentative, but the associations at Sites 259, 260, and 263 suggest a sediment deeper than shelf.

Aucellina sp., a bivalve determined as Albian was recovered from one sample each at Sites 259, 260, and 263 and described and figured by Speden (this volume). The material consists mostly of fragments and some juvenile forms. At Sites 259 and 260 the specimens occur in Cores 14 and $9 / 10$, respectively, together with rich foraminiferal and nannoplankton assemblages. One Belemnite, Parahibolithes sp. indet. was found in Core 26 at Site 263 and an Ammonite fragment, determined as ?cf. Prohysteroceras (Goodhallites) richardsi, was recovered from Site 263 , Core 18 . Both cephalopods indicative for upper Albians, are described and figured by Stevens (this volume).

While searching for isolated specimens of Calpionellids thought to be possibly present in the Lower Cretaceous/Upper Jurassic shales, Calcisphaerulidae, fossils of still uncertain systematic position and thus far almost exclusively figured and described from thin sections of limestones, were rather 
unexpectedly found. The small, spherical to elongate, single-chambered calcareous tests, most of them measuring $40-70 \mu$, are very restricted in their distribution. They are present in the Albian at Site 259, Cores 11-17; at Site 260 in the Upper Cretaceous of Core 6 ; and in the Albian of Cores 9-15. At Site 261 they are restricted to Cores 31-33, Upper Jurassic-Lower Cretaceous, where they occur in floods. Calcisphaerulidae of probably Albian age are rare at Site 263 where they were noted only in three samples.

Twenty-three different species (19 new, 4 in open nomenclature) could be recognized based on SEM investigation. They are distinguished by general test shape (spherical to elongate), number of layers (1-3) forming the test wall, size and arrangement of the crystals forming these walls, and size of the aperture. All are included in the genus Pithonella. Tentatively, it is assumed that the Calcisphaerulidae may represent a cyst stage of calcareous algae.

The stratigraphic ranges of the individual Pithonella species are restricted within the examined samples. As no known ages of these new taxa are available, the fossils' ages had to be tied in with the ages of other fossils present, in particular nannoplankton and foraminifera. A general introduction to the Calcisphaerulidae, a list of published taxa, and a description and illustration of the species isolated in Leg 27 are given by Bolli (this volume, Chapter 39).

Despite a lack of knowledge of the full ranges and a lack of correlations with stratotype sections of the faunas and floras used in these studies, little disagreement exists in the Leg 27 Cretaceous/Upper Jurassic age assignments based on the various fossil groups. Mostly discrepancies lie within a stage, e.g., at Site 259 where for Cores 11-17 benthonic foraminifera indicate upper Albian; planktonic foraminifera, Albian; and nannoplankton, middle Albian.
The only real exception to this is in the Cretaceous at Site 263 which is over 600 meters thick in Cores 5-29. Nannoplankton indicates upper Albian for most of this interval (Cores 5-27), based on frequent occurrence in Cores 22-27 of Eiffellithus turriseiffeli, an index form generally acknowledged to first appear in the upper Albian. This age assignment finds some support by an Ammonite fragment from Core 18 and a Belemnite from Core 26.

Judging from the considerable thickness, one is inclined, however, to assume that the interval may represent more time than only upper Albian. One could argue therefore that, based on nannoplankton, only the lower part, that is, Cores 22-27 with frequent $E$. turriseiffeli, is upper Albian and the upper part Cores 521 , though not documented by fossil evidence, is slightly younger, possibly Cenomanian.

A longer interval, ranging from lower Albian to Barremian/Neocomian, is postulated by benthonic foraminifera and palynomorphs. However, evidence for this, in particular with regard to the foraminifera, is apparently not based on outstanding index forms.

Further information on the full ranges of all taxa concerned will be needed before these discrepancies in age assignment within the Lower Cretaceous at Site 263 can be resolved satisfactorily.

\section{REFERENCE}

Bolli, H. M. and Premoli Silva, I., 1973. Oligocene to Recent planktonic foraminifera and stratigraphy of the Leg 15 sites in the Caribbean Sea. In Edgar, N. T. and Saunders, J. B. et al., Initial Reports of the Deep Sea Drilling Project, Volume 15: Washington (U.S. Government Printing Office). p. 475-547. 